\section{Audits as a Vaccine or Just Aspirin?}

\section{Timotej Jagrič ${ }^{1}$}

University of Maribor, Faculty of Economics and Business, Slovenia

timotej.jagric@um.si

\section{Tomaž Lešnik ${ }^{2}$}

Financial Administration of the Republic of Slovenia, Ljubljana, Slovenia lesnik.tomaz@amis.net

\begin{abstract}
This paper examines the impact of audits on voluntary tax compliance in the area of value added tax in Slovenia. The analyses argues that audited taxpayers with additional tax assessments as the result of an audit display a higher level of tax compliance within the year of the audit as within the year before audit, while audited taxpayers with no irregularities on the basis of an audit do not change their behavior significantly within the same period. However, regarding the longterm effect, the results reveal the possibility of worsening tax compliance with respect to audits where an additional tax assessment was imposed and where no irregularities were discovered during an audit.
\end{abstract}

Key words: audits, value added tax, voluntary tax compliance

\section{Introduction}

Tax compliance is one of the evident areas of modern tax systems. When considering the definition of term "tax compliance" OECD (2008) states that there are four basic tax compliance obligations of citizens and businesses that must be administered by all revenue bodies in accordance with their respective tax laws:

- To register for tax purposes;

- To file tax returns on time (i.e. by the date stipulated in the law) or at all;

- To correctly report tax liabilities (including as withholding agents); and

- To pay taxes on time (i.e. by the date stipulated in the law).

Increasing the level of voluntary tax compliance among taxpayers is one of the important goals of fiscal policy. In this context several OECD, IMF and other studies that propose different strategies on how to influence tax compliance, can be put forward. E.g., OECD (2010) states that all revenue bodies share a common mandate, namely to ensure a high level of compliance with the various tax laws and regulations. To ensure compliance a revenue body has to influence the compliance behavior of its taxpayer population. IMF (2009) suggests a tax compliance strategy for tax administrations in order to address the challenges of economic crisis. In this respect, tax administrations are considered to be the most important

\footnotetext{
1 The author acknowledges the financial support from the Slovenian Research Agency (research core funding No. P5-0027).

2 The views and opinions expressed in this article are those of the author and do not necessarily reflect the opinion of the Financial Administration of the Republic of Slovenia.
}

ORIGINAL SCIENTIFIC PAPER

RECEIVED: JULY 2017

REVISED: OCTOBER 2017

ACCEPTED: OCTOBER 2017

DOI: 10.1515/ngoe-2017-0020

UDK: 336.225.64:3.072.6

JEL: H21, H26

Citation: Jagrič, T., \& Lešnik, T. (2017).

Audits as a Vaccine or Just Aspirin?.

Naše Gospodarstvo/Our Economy, 63(4),

17-28. DOI: 10.1515/ngoe-2017-0020

\section{NG \\ OE}

NAŠE GOSPODARSTVO OUR ECONOMY

\section{Vol. 63 No. $4 \quad 2017$}

pp. 17- 28 
agencies and the direct contact point of taxpayers with the fiscal authorities. With the performance of their basic task i.e. revenue collection, tax administrations are fulfilling legally determined measures with an impact on taxpayer behavior. Being the most obvious, enforced (deterrent) measures are directed especially towards control and the prevention of noncompliance. These include audits, penalty activities and the enforced collection of tax debts. Certainly, tax administrations use numerous other techniques for the purpose of promoting the positive behavior of taxpayers. Thus, timely and complete information for taxpayers is important, as well as efficient communication between the tax administration and taxpayers. Promoting electronic methods for the fulfillment of tax obligations, introducing simpler ways in order to facilitate the payment of taxes and other (softer) measures might also be included in this group.

In this context, we should also consider the question of the efficiency of the respective measures, i.e. to what extent they actually influence the willingness of taxpayers for voluntary tax compliance. In our paper we focus on the effects of the enforced measures, namely: to assess the impact of audits being performed on the level of tax compliance in the area of value added tax (VAT). In the case of Slovenia, we want to establish the findings of some other studies of individual willingness for tax compliance, which have shown the worsening of tax compliance in cases where audits with an additional tax assessment has been performed, e.g. Bergman and Nevarez (2006). Thus, the audited taxpayers may have revealed the worsening of tax compliance in the year after an audit, especially those where more irregularities were discovered during an audit and the additional tax assessment is being imposed, respectively. While engaging in tax avoidance such taxpayers would have tried to compensate the additional tax assessment arising from an audit being performed.

In our analysis we also examine the long-term impact of audits on the level of voluntary tax compliance. Namely, we were interested in the behavior of audited taxpayers for a period of several years after an audit has been performed. Is the level of tax compliance in the years after an audit increasing or maybe worsening? Do audits have the effect of a vaccine with long-term (sustainable) lasting power, or is it instead a short-term effect, like a pill for a headache (aspirin)? In this connection, we found that there is lack of studies, which examines long-term effect of audits.

A special challenge is in determining a measurable category that reflects the level of tax compliance (regarding VAT). A possible approach is to estimate the VAT tax gap on the basis of data from national accounts, which was presented by CASE (2013) and before that Reckon (2009). Well known is also the ratio of revenues from VAT and the potential
VAT base, the so-called VRR ratio (VAT revenue ratio). The potential tax base is calculated as the product of all final consumption expenditures and the standard VAT rate (OECD, 2014). Some studies, however, focus in this regard on the collected revenues, e.g. Aizenman and Jinjirak (2008) and Matthews (2003). Bergman and Nevarez (2006) have applied data on the VAT returns being filed, namely the ratio of VAT obligation and surplus as an indicator of the level of tax compliance. In our analysis, due to data availability, methodological simplicity and clearness we decided to apply the data on VAT returns, as a measure of tax compliance.

Our analysis assesses the short and long-term impact of audits in comparison to some other studies that examine mainly the short-term effect of audits, e.g. Bergman and Nevarez (2006). We believe that long-term effect of audits should also be considered when examine the impact of audits on tax compliance. Based on samples of audited and non-audited taxpayers we compare the net effect (net obligation) from VAT returns being filed. In the short term, we have defined the differences in net effect in the year of an audit and in the year after an audit, both in comparison with the year prior to an audit. To assess the long-term impact we compared the differences in net effects for a period of two years and more after an audit was performed.

\section{Literature Review}

The examination of factors with the influence on voluntary tax compliance is the subject of numerous studies. OECD (2010) with respect to the effective mission of tax administrations presents several categories with an impact on the behavior of taxpayers, namely: deterrence, norms, opportunities, fairness, economic factors, and interactions.

Empirical investigations into the relationship between tax compliance and fiscal administration measures, especially audits, are not new; Allingham and Sandmo (1972) already studied some of the static and dynamic aspects connected to the decision to evade taxes, while considering deterrence measures within the context of a proposed model. Dubin and Wilde (1988) provided empirical evidence on the relationship between compliance with the Federal Income Tax and auditing by the Internal Revenue Service (IRS). Likewise, Alm et al. (1992) empirically showed that taxpayer reporting increases along with greater audits and penalty rates. The importance of detection and punishment in cases of noncompliance is recognized by Alm et al. (1995), although a government compliance strategy that is solely based on detection and punishment may well be a reasonable starting point but not a good ending point. Kamdar (1997) analyzed aggregate time series data on 
corporate compliance and showed audits to be an effective deterrent to noncompliance but his results cast doubt on the presumption that higher penalties or lower tax rates lead to improved compliance. The audit rate and the penalty rate both being effective deterrents to noncompliance was established by Ali et al. (2001), while the effectiveness of these two policy instruments depends upon the individual's level of income. It seems that the higher the income level, the more effective these instruments are. Also, Plumley (2002) found a statistically significant impact for some IRS activities on tax compliance, including audits and criminal investigations. Kleven et. al (2011) conducted a tax enforcement field experiment in Denmark. As a representative sample they selected over 40,000 individual income tax filers. Half of the tax filers were randomly selected to be thoroughly audited, while the rest were deliberately not audited. The following year threat-of-audit letters were randomly assigned and sent to tax filers in both groups. With the usage of the randomization of the enforcement, the authors found that prior audits and threat-of-audit letters have a significant effect on self-reported income, but no effect on third-party reported income. Hoopes et al. (2012) studied the influence of audits on future tax compliance and proved a positive correlation. The authors stated that American public companies take a less aggressive tax position in the case of more severe tax enforcement (in the case of a higher probability of an audit). Gemmel and Ratto (2012) argue that random audit programs provide income taxpayers with information that alters their perceptions of, and hence their behavioral responses to, audits. Comparing samples of randomly selected audited and non-audited UK taxpayers, the authors confirm the prediction that audited taxpayers who were found to be compliant reduce their subsequent compliance. The opposite response is observed for taxpayers found to be noncompliant. Agostini and Martinez (2014) analyzed the impact of a tax enforcement programme implemented by the Chilean Internal Revenue Service (IRS), where letters requiring information about diesel purchases and use and vehicle ownership were sent to around 200 firms in 2003. Using different empirical strategies to consider the non-randomness of the selection of firms, their empirical results showed consistently that firms receiving a letter containing the threat of an audit decreased their diesel tax credits by around 10 per cent. Hauptman et al. (2014) explored the experience of taxpayers with audits and on the basis of empirical results for Slovenia found that $71.8 \%$ taxpayers were satisfied with the audit. At the same time, the authors recommended that the tax administration continue with the application of new possibilities for the purpose of strengthening the level of tax compliance. An important investigation on how long-lasting is the effects of audits on reported tax liability was conducted by Advani, Elming and Shaw (2015). Their results suggested that there is a large and persistent impact of audits on reported tax liability that reaches around 26 per cent by the fourth year following the tax year to which audits relates.

Unlike studies that emphasize the positive correlation between the enforcement measures of tax administrations and tax compliance, Bergman and Nevarez (2006), in the case of Argentina and Chile, reject the statement that audits in relative countries directly increase individual tax compliance. The authors applied data on VAT returns with respect to audits being performed and showed that audits have the undesired effect of furthering noncompliance behavior among cheaters but a more positive effect among those prone to compliance. Their empirical analysis supports the assumption that the effects ofwadditional assessments on individuals are offset by higher subsequent evasion, presumably to compensate for taxpayers' costs incurred during audits (ibid). Choo et al. (2013) performed an experiment on tax-compliance behavior on a sample of 92 self-assessed taxpayers. They found that raising the audit rate did not change the compliance level of self-assessed participants. Also, increasing audit rates did increase total revenue, but that result was only significant for an individual sample in the first set of experiments. The next finding was that increasing the audit rate led to a very small and not statistically significant drop in the tax gap (the difference between the maximum collectable tax revenue and the actual collected revenue) in all samples. The authors did not find any evidence that compliance levels dropped immediately after an audit (the bomb-crater effect), either in compliant participants or in non-compliant ones.

\section{Data and Methods}

For the measure of VAT compliance, we introduced the net VAT obligation based on VAT returns from the Financial Administration of the Republic of Slovenia (FARS) database. The net VAT obligation is defined as the difference between the VAT obligation and VAT surplus (both categories are included in VAT returns). In this respect, the VAT obligation derives from the recorded taxable turnover and VAT surplus derives from the recorded purchases (VAT from purchases is being put forward as already paid and therefore it reduces the VAT obligation). Bergman and Nevarez (2006) also applied similar measures although they employed the ratio of VAT obligations and surplus as an indicator of the level of tax compliance.

The purpose of our analysis is to establish the differences in the presented net VAT obligation for audited and non-audited taxpayers, between the periods before, during and after audits are performed. The data for analysis is based on the sample of VAT returns being filed. For this purpose we have obtained the data on audited taxpayers $(\mathrm{N}=790)$ from 
FARS evidence on performed audits (all audited taxpayers in the year 2008 in the area of VAT), as well as the sample of non-audited taxpayers, who represent a control group ( $\mathrm{N}=1798)$. The control group is adjusted to the audited group in terms of the economic sector, form of economic activity (micro, small, medium, large taxpayers and associations) and the region where the economic activity was performed.
On Figure 1 one can observe the characteristics of audited and control group in terms of the form of economic activity. It is evident that the majority of taxpayers are organized as micro companies.

Figure 2 presents the characteristics of audited and control group in terms of economic sector. The following sectors are included: A - agriculture, hunting, forestry and fishing,

Figure 1. Characteristics of audited and control group in terms of the form of economic activity (in \%)

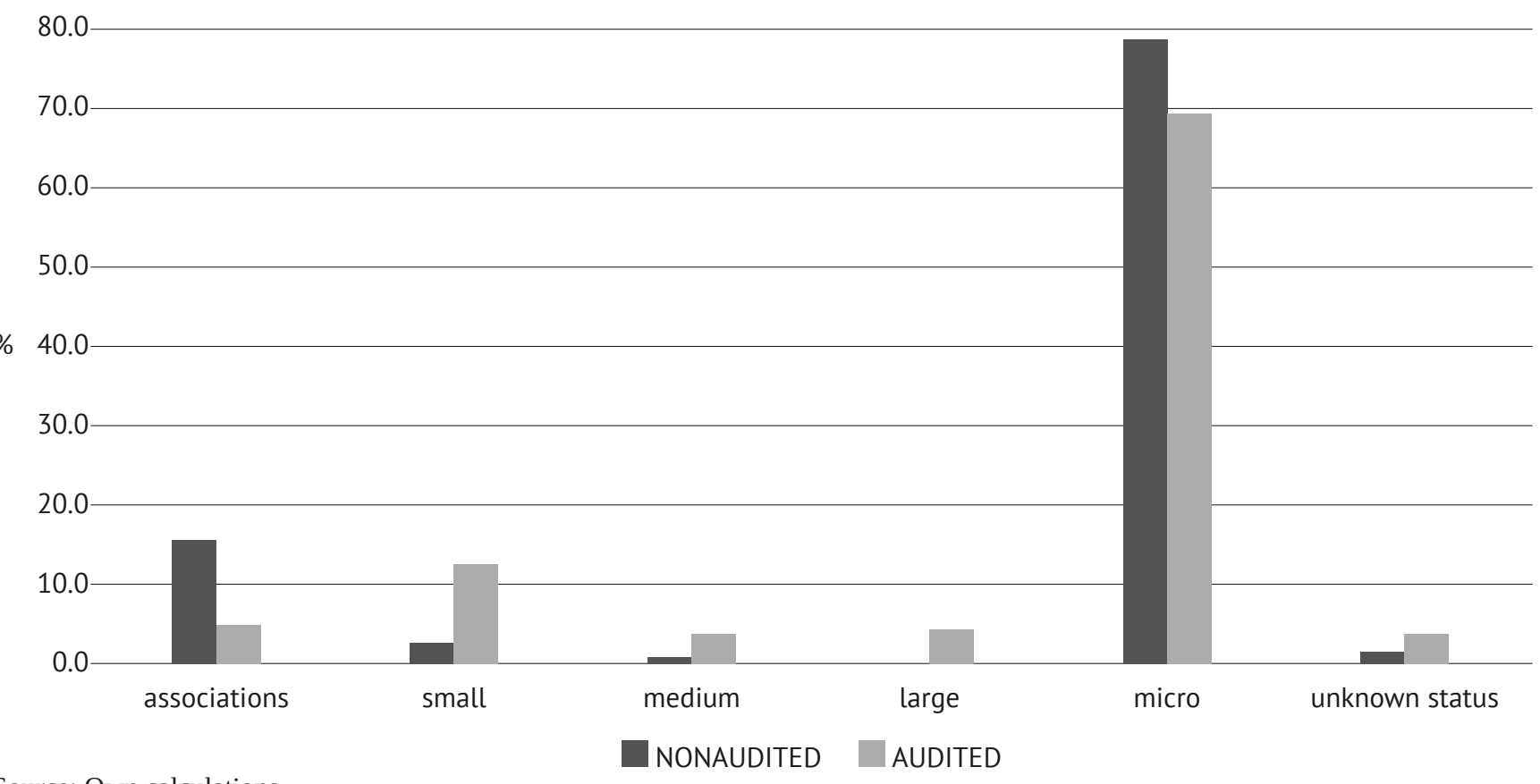

Source: Own calculations

Figure 2. Characteristics of audited and control group in terms of economic sector (in \%)

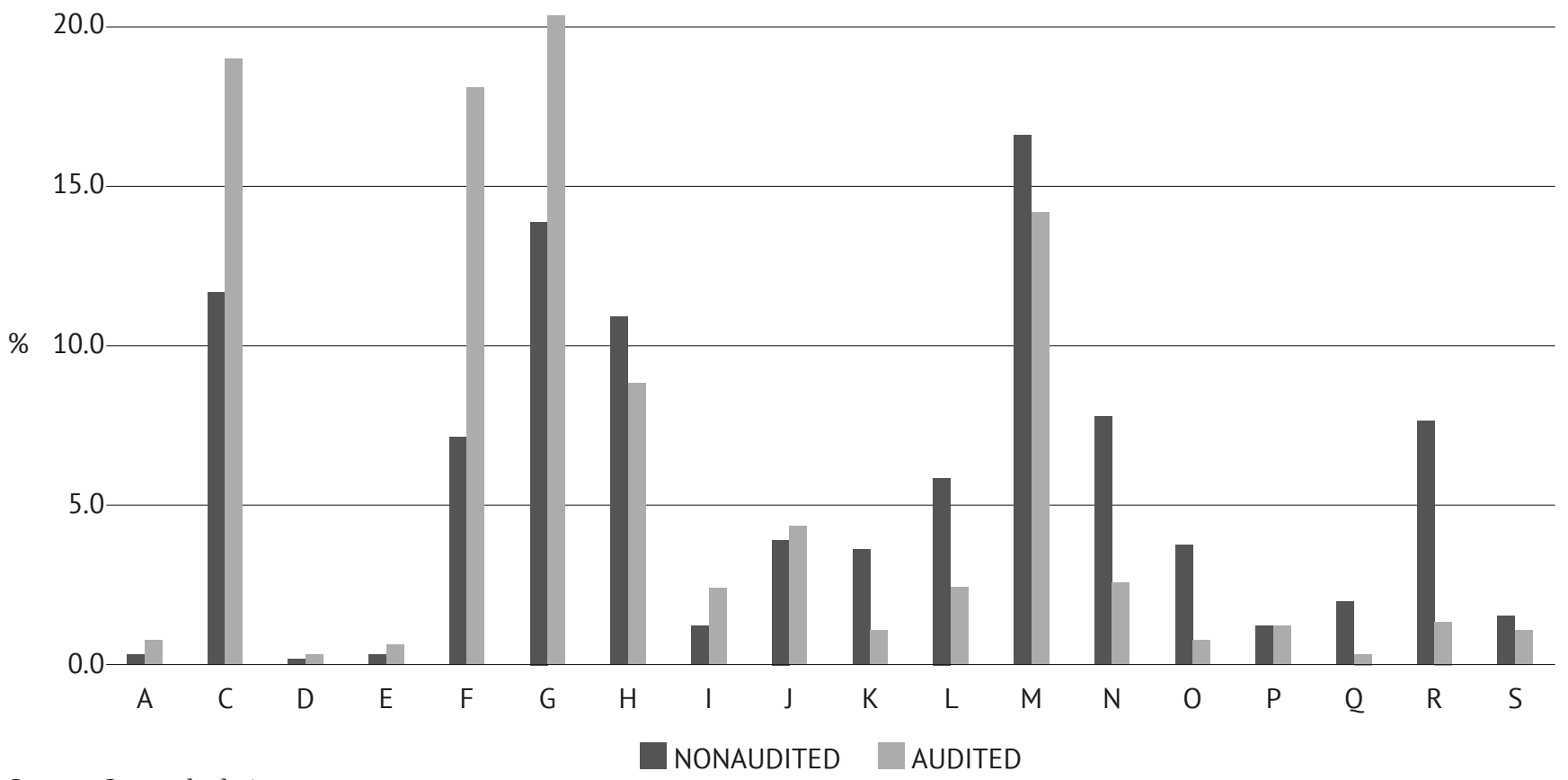

Source: Own calculations 
C - manufacturing, D - power, gas and steam supply, E water supply, waste and sewage management, sanitation of environment, F - construction, G - trade, maintenance and repair of motor vehicles, $\mathrm{H}$ - traffic and storage, $\mathrm{I}$ - hotel and pub management, $\mathrm{J}$ - information and communication activities, $\mathrm{K}$ - financial and insurance activities, L - management of real estates, $\mathrm{M}$ - professional, science and technical activities, $\mathrm{N}$ - other different business activities, $\mathrm{O}$ - public administration and defense activities, $\mathrm{P}$ - education, $\mathrm{Q}$ - health and social care, $\mathrm{R}$ - cultural, relaxation and recreation activities, $\mathrm{S}$ - other activities (such as unions, political activities, etc.). It is observable that the largest groups of taxpayers were active on the areas of manufacturing, construction, trade, maintenance and repair of motor vehicles, traffic and storage and professional, science and technical activities.

Figure 3 presents the distribution of taxpayers according to the region of performing the economic activity. Each region is taking different value from 3 to 21 . The majority of taxpayers are active on the area of region 8. This region represents central Slovenia, which is the most developed area with the largest number of different businesses.

Our analysis was designed according to the principles of treatment effect studies. We included three types of taxpayers in the study:

- $\quad$ audited and sanctioned taxpayers (taxpayers, where additional taxes were imposed during an audit) ;

- audited but not sanctioned taxpayers (taxpayers, where no incorrectness was discovered during an audit);

- $\quad$ taxpayers who were not audited - the control group.
Each taxpayer was followed from 2007 to 2013. The audit was performed in 2008. We included those taxpayers who were audited only once. Taxpayers in the control group were not audited during the observed period.

For all three groups of taxpayers, we calculated the median of net VAT obligation for the individual year, as well as the differences between the years 2008 and 2007, 2009 and 2007, 2010 and 2007, 2011 and 2007, 2012 and 2007, 2013 and 2007 (thus, the differences between the medians of net VAT obligation for the periods before, during, and after audits have been performed).

In the process of developing a data set, which we used in further analysis, we had to deal with two problems. First, the data are strictly confidential and prepared by FARS, which means that we had no direct control on the selection process. We received only information about the net VAT obligation in a selected year, and an audit flag. Second, there was high heterogeneity in the properties of the taxpayers, which we cannot control directly in the analysis because we do not have additional information on the properties of each taxpayer in the sample. High heterogeneity manifested as large differences between values of net VAT obligations within the group of audited taxpayers and within control group. We, therefore, developed three subsamples:

- Sample one - includes all available observations. Excluded are only those with missing data.

- Sample two - we first excluded observations with missing data and then applied trimming. We excluded

Figure 3. Characteristics of audited and control group in terms of the region where the economic activity was performed (in \%)

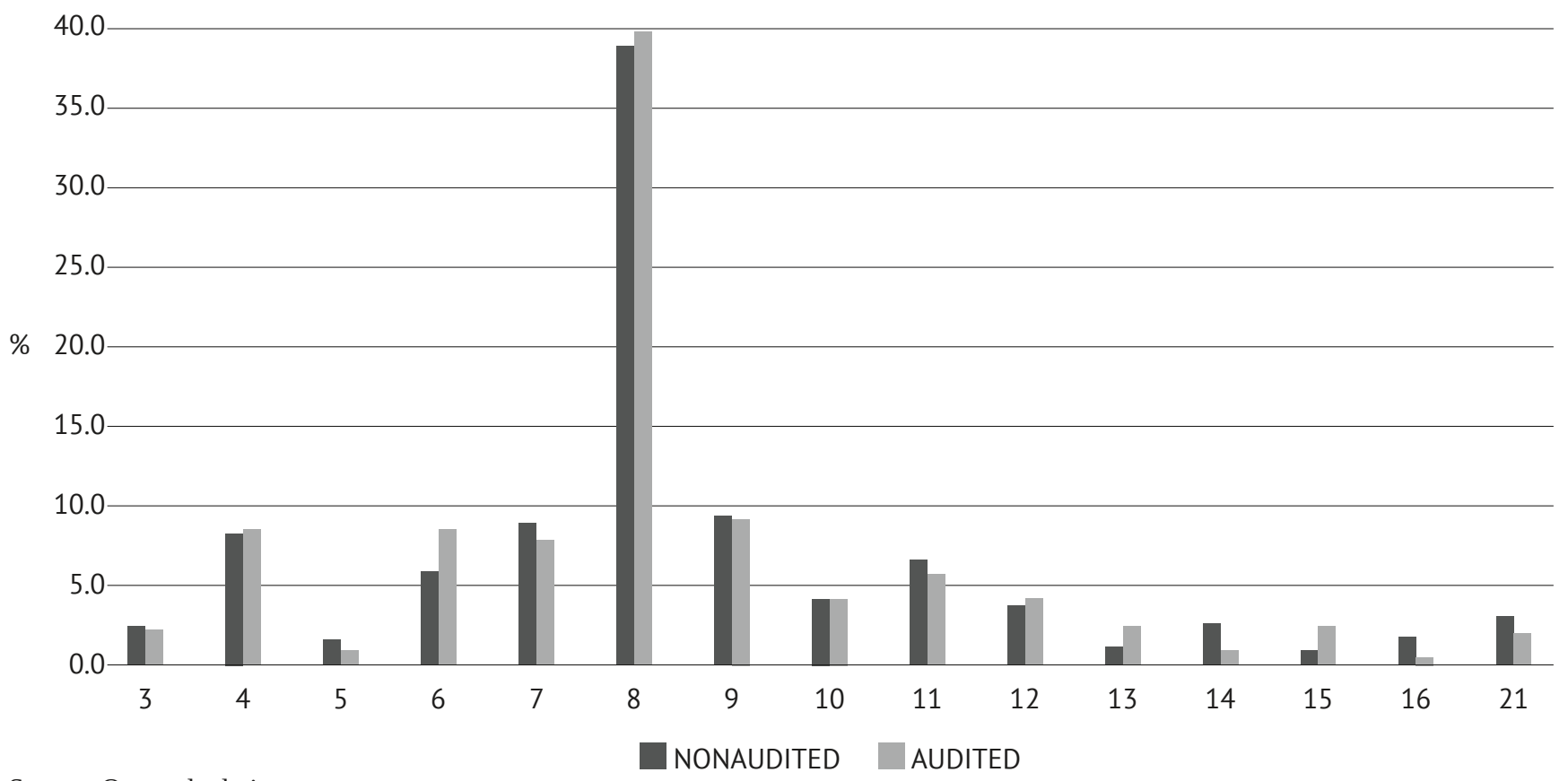

Source: Own calculations 
$5 \%$ of extreme values on each side of the distribution (in total, $10 \%$ of all observations).

- Sample three - we applied Winsorising to limit the extreme values. All observations below the 5th percentile were set to the 5th percentile, and observations above the 95th percentile set to the 95th percentile. We used a procedure developed by Cardillo (2011).

In this way we indirectly test the effect of heterogeneity on the results by dealing with outliers. As noted by Cardillo (2011), the distribution of many statistics can be influenced by outliers. Therefore, we compared the results for all three subsamples. Table 1 shows the sample sizes for each year.

Analysis of the effect of the audit on taxpayers was done in three steps. First, we applied a Kruskal-Wallis test. It's a non-parametric method for testing the equality of population medians between groups. The test works are an extension of the Mann-Whitney U test because we can compare three groups. It does not assume a normal population, but requires an identically-shaped and scaled distribution for each group. The distribution of the Kruskal-Wallis statistics was approximated by three distributions: chi-square approximation (most conservative), F approximation (less conservative), Beta and Gamma approximations (Cardillo, 2009).

Because we detected differences among groups, we applied a second step. The goal was to isolate the differences among groups. We used a Dunn-Sidak test. This is a procedure for multiple non-parametric comparisons. It is applicable for equal or unequal sample sizes. The test was performed with a procedure, developed by Cardillo (2006).
Finally, we also performed a cross-check of the obtained results, by simple regression analysis with an OLS estimator. The dependent variable is presented by yearly changes of medians of net VAT obligation in the period from 20072013. We apply medians instead of averages due to large differences between net VAT obligations of individual taxpayers. We know that some crucial assumptions have been violated, but due to the large sample, we think that the results are good enough to support our findings in step one and two. The basic statistical properties of the depended variable, which also show no normal distribution are in Figure 4.

\section{Analysis}

Figure 5 shows the changes in the medians of net VAT obligation during audits (in 2008) and after audits have been performed (2009-2013) in comparison to the period before audits (2007) for all three groups. The period before audits were performed has the index value 100 . With the control group the revealed net VAT obligations in 2008 remain on the same level as at the starting point, followed by a decline during the remaining period. A similar fluctuation can be observed regarding the group of audited but not sanctioned taxpayers, although the median of reported net VAT obligations decreased for the entire analyzed period. However, in contrast to both relative groups, the audited and sanctioned taxpayers increased their net VAT obligation in 2008 (the year of audit). Then the net VAT obligation starts to fall, but remains on a higher level as the net VAT obligation of

Table 1. Sample size by year, group and method of creating the sample

\begin{tabular}{llcccccc} 
& \multicolumn{1}{c}{ Year } & & & & \\
& Group & 2008 & 2009 & 2010 & 2011 & 2012 & 2013 \\
\hline Full sample & 1 & 1798 & 1798 & 1798 & 1798 & 1798 & 1798 \\
\hline & 2 & 304 & 304 & 304 & 304 & 304 & 304 \\
\hline & 3 & 486 & 486 & 486 & 486 & 486 & 486 \\
\hline Trimmed sample & Total & 2588 & 2588 & 2588 & 2588 & 2588 & 2588 \\
\hline & 2 & 1630 & 1616 & 1626 & 1618 & 1618 & 1622 \\
\hline Winsored sample & 1 & 263 & 266 & 260 & 265 & 265 & 260 \\
\hline & 3 & 437 & 448 & 444 & 447 & 447 & 448 \\
\hline & Total & 2330 & 2330 & 2330 & 2330 & 2330 & 2330 \\
\hline & 3 & 1798 & 1798 & 1798 & 1798 & 1798 & 1798 \\
\hline & Total & 304 & 304 & 304 & 304 & 304 & 304 \\
\hline
\end{tabular}

Note: Group 1 - control group, Group 2 - audit but not sanctioned, Group 3 - audit and sanctioned.

Source: Own calculations 
Figure 4. Basic statistical analysis of dependent variable
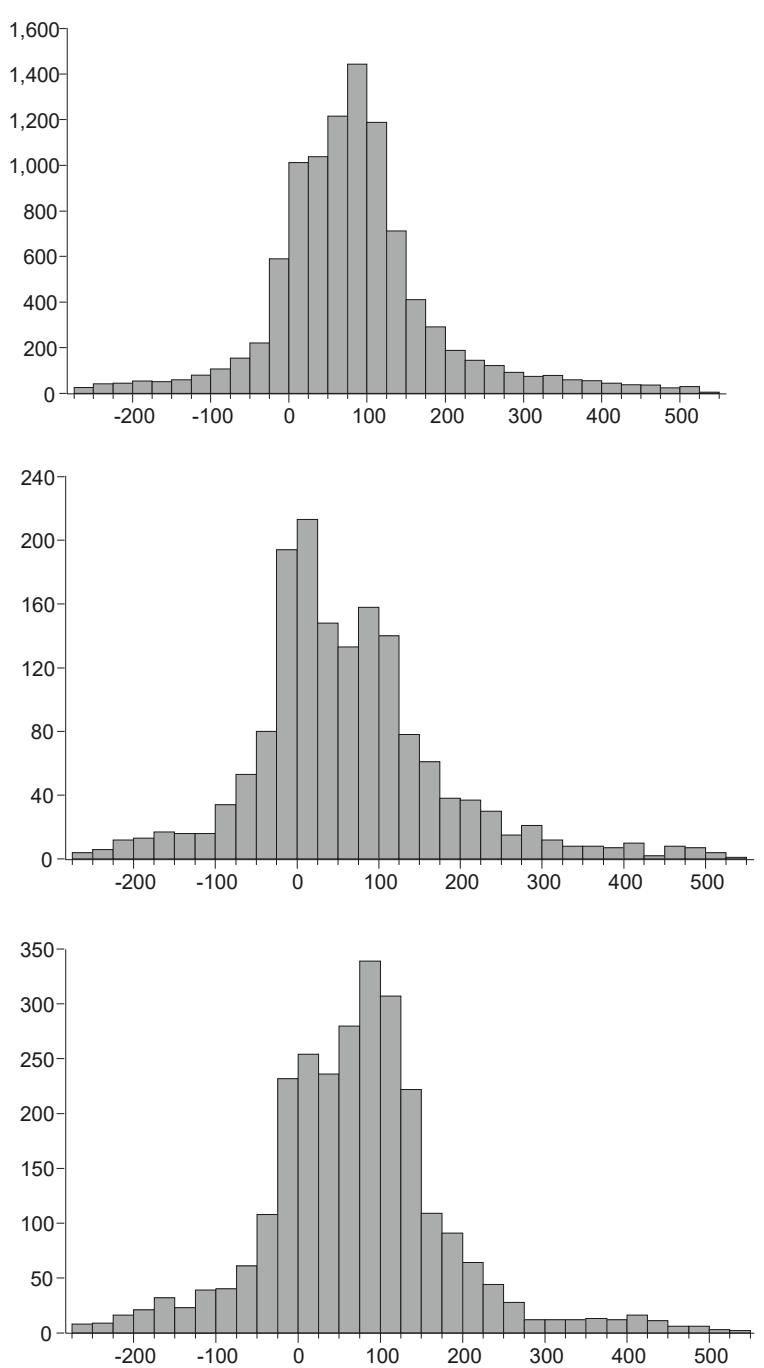

\begin{tabular}{lr}
\multicolumn{2}{c}{ Group 1} \\
Observations & 9724 \\
& \\
Mean & 83.96518 \\
Median & 77.84561 \\
Maximum & 531.1748 \\
Minimum & -270.1122 \\
Std. Dev. & 107.9643 \\
Skewness & 0.697332 \\
Kurtosis & 5.818212 \\
& \\
Jarque -Bera & 4006.049 \\
Probability & 0.000000
\end{tabular}

\section{Group 2}

Obsenvations 1584

$\begin{array}{lr}\text { Mean } & 62.52286 \\ \text { Median } & 44.92812 \\ \text { Maximum } & 528.4460 \\ \text { Minimum } & -265.8834 \\ \text { Std. Dev. } & 118.2467 \\ \text { Skewness } & 0.806887 \\ \text { Kurtosis } & 5.026128 \\ & \\ \text { Jarque -Bera } & 442.8247 \\ \text { Probability } & 0.000000\end{array}$

\section{Group 3}

Observations 2668

Mean $\quad 72.06000$

Median $\quad 72.36407$

Maximum 525.7134

Minimum $\quad-267.8983$

$\begin{array}{ll}\text { Std. Dev. } & 110.2180 \\ \text { Skewness } & 0.450923\end{array}$

Kurtosis $\quad 5.121024$

Jarque-Bera 590.5252

Probability 0.000000

Note: Group 1 - control group, Group 2 - audit but not sanctioned, Group 3 - audit and sanctioned Source: Own calculations

both other groups. After 2009, the net VAT obligation of this group falls below the net VAT obligation of the control group. However, it remains on a higher level than the net VAT obligation of the audited but not sanctioned group.

In addition, a general downward trend of net VAT obligations is apparent from Figure 5. The authors assume that such fluctuation is connected with the economic crisis stared in 2008 .

After a simple graphical analysis based on Figure 5, we proceeded with a statistical analysis, which was performed in three steps. First, by applying Kruskal-Wallis test, we tested whether there were differences between all three groups. In the second step, we applied a Dunn test in order to identify which pairs of groups are statistically significant differences in medians. Finally, in the third step we performed a regression analysis in order to test differences in averages between groups.
The results of testing for the statistical significance of differences between groups for the year 2008 show no differences between the groups, except when considering a trimmed sample (Table 2); the trimmed sample has no extreme values and, therefore, compares more homogenous groups. From 2009 onwards, all three variants of sample provide the same results. There is a significant statistical difference between the groups.

In order to identify the source of positive Kruskal-Wallis test results, we further applied a Dunn test. The results are presented in Table 3 and Table 4 . The results suggest that H0 was rejected with respect to the trimmed sample (the differences between medians exist between the control group and audited but not sanctioned taxpayers; and between audited and sanctioned and audited but not sanctioned taxpayers). The testing for statistically significant differences on the basis of comparing the medians for 2008 do not provide clear results. 
Considering 2009, the testing for differences in medians presents more clear results. From Table 4, it is evident that there are statistically significant differences between the control group and audited but not sanctioned taxpayers, as well as between audited and sanctioned and audited but not sanctioned taxpayers. However, we cannot confirm the differences between audited and sanctioned taxpayers and the control group.
As for the period from 2010-2013, the results of testing for differences in medians show that there are statistically significant differences between the control group and both of the audited groups.

Finally, we also performed a regression analysis in order to test the differences in medians for three groups. The results

Figure 5. The changes in medians of net VAT obligation for all of three groups of taxpayers (year $2007=100$ )

120

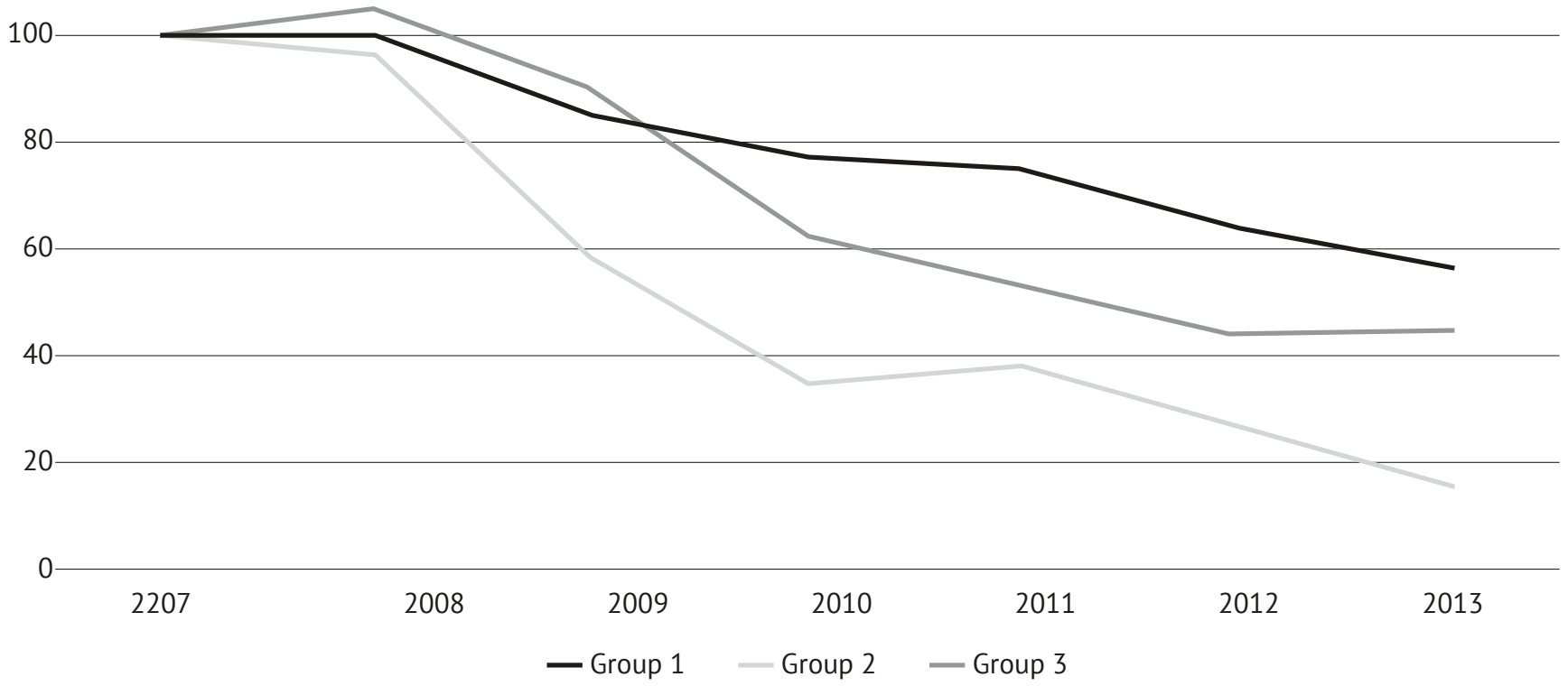

Note: Group 1 - control group, Group 2 - audit but not sanctioned, Group 3 - audit and sanctioned

Source: Own calculations

Table 2. Kruskal-Wallis test

\begin{tabular}{llcccccc} 
& \multicolumn{1}{c}{ Year } & & & & \\
& Distribution approximation & 2008 & 2009 & 2010 & 2011 & 2012 & 2013 \\
\hline Full sample & Chi-square & 0.2589 & 0.0000 & 0.0000 & 0.0000 & 0.0000 & 0.0000 \\
\hline & F-statistic & 0.2587 & 0.0000 & 0.0000 & 0.0000 & 0.0000 & 0.0000 \\
\hline & Beta & 0.2590 & 0.0000 & 0.0000 & 0.0000 & 0.0000 & 0.0000 \\
\hline & Gamma & 0.2589 & 0.0000 & 0.0000 & 0.0000 & 0.0000 & 0.0000 \\
\hline Trimmed sample & Chi-square & 0.0179 & 0.0000 & 0.0000 & 0.0000 & 0.0000 & 0.0000 \\
\hline & F-statistic & 0.0177 & 0.0000 & 0.0000 & 0.0000 & 0.0000 & 0.0000 \\
\hline & Beta & 0.0178 & 0.0000 & 0.0000 & 0.0000 & 0.0000 & 0.0000 \\
\hline Winsored sample & Gamma & 0.0178 & 0.0000 & 0.0000 & 0.0000 & 0.0000 & 0.0000 \\
\hline & Chi-square & 0.2627 & 0.0000 & 0.0000 & 0.0000 & 0.0000 & 0.0000 \\
\hline & F-statistic & 0.2625 & 0.0000 & 0.0000 & 0.0000 & 0.0000 & 0.0000 \\
\hline & Beta & 0.2628 & 0.0000 & 0.0000 & 0.0000 & 0.0000 & 0.0000 \\
\hline & Gamma & 0.2627 & 0.0000 & 0.0000 & 0.0000 & 0.0000 & 0.0000 \\
\hline
\end{tabular}

Note: Results are presented by $\mathrm{p}$ - values.

Source: Own calculations 
are presented in Table 5. For 2008, the results indicate that sanctions during an audit have a statistically significant positive impact on reported higher net VAT obligations. A similarly statistically significant impact was not discovered regarding audited but not sanctioned taxpayers.

For 2009, the results from a regression analysis in Table 5 provide similar results as the Dunn test. We can observe a statistically significant negative impact on reported net VAT obligations regarding audited but not sanctioned taxpayers, while the impact with respect to audited and sanctioned taxpayers cannot be confirmed. After 2009, the regression results reveal a significant negative influence on the reported net VAT obligation for audited taxpayers - audited taxpayers who were sanctioned and audited taxpayers who were not sanctioned.

\section{Discussion and Conclusion}

From a simple graphical analysis in Figure 5, it is evident that there is a short-term positive effect of audits and sanctions in the year of audit (2008); however, with tests being applied we cannot clearly confirm this. We assume that the reason behind this is in the high heterogeneity in the properties of taxpayers. The behavior of audited but not sanctioned taxpayers for the year of audit shows that there are no considerable differences than can be found in the control group. In the year 2009 (one year after audits are performed) the behavior of audited and sanctioned taxpayers is very similar to the behavior of the control group (there are no statistically significant differences between these two groups). On the other hand, from Figure 5, we

Table 3. Dunn test (q-values)

\begin{tabular}{|c|c|c|c|c|c|c|c|c|c|}
\hline \multirow[b]{3}{*}{ Full sample } & \multirow{2}{*}{\multicolumn{3}{|c|}{ Hypothesis }} & \multicolumn{6}{|c|}{ Year } \\
\hline & & & & \multirow{2}{*}{$\begin{array}{c}2008 \\
0.9694\end{array}$} & \multirow{2}{*}{$\begin{array}{l}2009 \\
4.148 \\
\end{array}$} & \multirow{2}{*}{$\begin{array}{c}2010 \\
5.068 \\
\end{array}$} & \multirow{2}{*}{$\begin{array}{c}2011 \\
3.2916 \\
\end{array}$} & \multirow{2}{*}{$\begin{array}{c}2012 \\
4.4958 \\
\end{array}$} & \multirow{2}{*}{$\begin{array}{r}2013 \\
5.3659\end{array}$} \\
\hline & 1 & vs & 2 & & & & & & \\
\hline & 1 & vs & 3 & NA & 1.5445 & 3.1843 & 3.7965 & 3.8322 & 2.6036 \\
\hline & 3 & vs & 2 & 1.6171 & 4.5975 & 2.0716 & 0.1371 & 1.1334 & 2.7303 \\
\hline \multirow[t]{3}{*}{ Trimmed sample } & 1 & vs & 2 & 2.5441 & 4.7335 & 4.9658 & 4.1548 & 4.565 & 4.9121 \\
\hline & 1 & vs & 3 & 0.8013 & 1.601 & 3.1667 & 4.1743 & 3.6643 & 2.7818 \\
\hline & 3 & vs & 2 & 2.7194 & 5.1507 & 2.0758 & 0.6744 & 1.3766 & 2.3046 \\
\hline \multirow[t]{3}{*}{ Winsored sample } & 1 & vs & 2 & 0.9635 & 4.1605 & 5.0437 & 3.2534 & 4.4721 & 5.344 \\
\hline & 1 & vs & 3 & NA & 1.5282 & 3.1969 & 3.786 & 3.825 & 2.6027 \\
\hline & 3 & vs & 2 & 1.6082 & 4.5968 & 2.0422 & 0.1121 & 1.1183 & 2.7123 \\
\hline
\end{tabular}

Note: Q-values, Critical Q = 2.3877, NA - no comparison made (Accept H0 - no difference in population medians), Group 1 - control group, Group 2 - audit but not sanctioned, Group 3 - audit and sanctioned.

Source: Own calculations

Table 4. Dunn test (decision based on q-values)

\begin{tabular}{|c|c|c|c|c|c|c|c|c|c|}
\hline \multirow[b]{3}{*}{ Full sample } & & & & \multicolumn{6}{|c|}{ Year } \\
\hline & \multicolumn{3}{|c|}{ Hypothesis } & 2008 & 2009 & 2010 & 2011 & 2012 & 2013 \\
\hline & 1 & vs & 2 & Fail & Reject & Reject & Reject & Reject & Reject \\
\hline & 1 & vs & 3 & Accept & Fail & Reject & Reject & Reject & Reject \\
\hline & 3 & vs & 2 & Fail & Reject & Fail & Fail & Fail & Reject \\
\hline \multirow[t]{3}{*}{ Trimmed sample } & 1 & vs & 2 & Reject & Reject & Reject & Reject & Reject & Reject \\
\hline & 1 & vs & 3 & Fail & Fail & Reject & Reject & Reject & Reject \\
\hline & 3 & vs & 2 & Reject & Reject & Fail & Fail & Fail & Fail \\
\hline \multirow[t]{3}{*}{ Winsored sample } & 1 & vs & 2 & Fail & Reject & Reject & Reject & Reject & Reject \\
\hline & 1 & vs & 3 & Accept & Fail & Reject & Reject & Reject & Reject \\
\hline & 3 & vs & 2 & Fail & Reject & Fail & Fail & Fail & Reject \\
\hline
\end{tabular}

Note: H0 - no difference in population medians, Group 1 - control group, Group 2 - audit but not sanctioned, Group 3 - audit and sanctioned; Fail: H0 is not rejected; Accept: H0 is not verified; Reject: H0 is rejected (there are differences between groups).

Source: Own calculations 
Table 5. Regression results for the dependent variable (changes of medians in net VAT obligations)

\begin{tabular}{|c|c|c|c|c|c|}
\hline Variable & Coefficient & Prob. & Variable & Coefficient & Prob. \\
\hline AUDIT-SANCTION & 8.0284 & 0.2374 & SANCTION & 21.1964 & 0.0001 \\
\hline (AUDIT-SANCTION)*Y2009 & -21.2515 & 0.0246 & SANCTION *Y2009 & -7.9837 & 0.2744 \\
\hline (AUDIT-SANCTION)*Y2010 & -37.1767 & 0.0001 & SANCTION *Y2010 & -40.2547 & 0.0000 \\
\hline (AUDIT-SANCTION)*Y2011 & -30.0590 & 0.0015 & SANCTION *Y2011 & -48.8764 & 0.0000 \\
\hline (AUDIT-SANCTION)*Y2012 & -40.7154 & 0.0000 & SANCTION *Y2012 & -51.5888 & 0.0000 \\
\hline (AUDIT-SANCTION)*Y2013 & -48.0991 & 0.0000 & SANCTION *Y2013 & -50.0602 & 0.0000 \\
\hline CONSTANT & 83.9652 & 0.0000 & & & \\
\hline F-statistic & 16.5702 & & \multicolumn{3}{|c|}{ Included observations: 13976} \\
\hline Prob(F-statistic) & 0.0000 & & \multicolumn{3}{|c|}{ Method: Least Squares } \\
\hline
\end{tabular}

Note: AUDIT - dummy for audited taxpayer, SANCTION - dummy for sanctioned taxpayer, AUDIT-SANCITON: audited but not sanctioned taxpayer; Y\#\#\#\# - dummy for year.

Source: Own calculations

can observe a negative decline regarding audited but not sanctioned taxpayers.

It also seems that our results do not support the assumption about the long-term positive impact of audits. Considering the period from 2010-2013 and Figure 5, we can observe a considerable negative decline for both of the audited groups in comparison with the control group. Also, audited and not sanctioned taxpayers reveal a deeper drop in reported net VAT obligations than audited and sanctioned taxpayers (with respect to the control group). We might conclude that the behavior of audited and sanctioned taxpayers has changed positively during audits and then slowly tends to be more non-compliant in the subsequent periods. Audited but not sanctioned taxpayers, however, did not change their behavior during audits. Yet, it still seems that they became non-compliant very quickly, namely one year after the audit their reported net VAT obligation began to fall rapidly.

Similar findings in relation to audited and sanctioned taxpayers have also been described by Bergman and Nevarez (2006) albeit on the basis of a shorter observation period. Thus, the findings of our analysis support the assumption that taxpayers with the imposed additional tax assessment arising from an audit try to compensate for their "punishment" via a lower reporting in VAT returns in the years after an audit. Concerning non-sanctioned taxpayers, it seems that our results point towards the taxpayer calculating that there is a low probability of being audited again after a previous audit revealed no irregularities. The low probability of an audit as one of factors that could affect tax compliance has been the subject of several studies which address the issue of tax compliance (e. g. Palil and Mustapha, 2011). Finally, when considering the long-term impact of audits in light of the results of our analysis, such results might suggest that audits have the effect of a pile of aspirin with only temporary lasting power instead of having the effect of a vaccine with more sustainable lasting power.

We also believe that it is necessary to draw attention to the fact that the period of our analysis coincides with the beginning of economic crisis, which according to some research significantly worsens the level of tax compliance. Although we found only a few studies that addressed the issue of tax compliance and the business cycle, all respective studies tend to confirm the likelihood of a macroeconomic negative impact. Thus, Lešnik et al. (2014a) econometrically assessed the influence of recession on the tax debt increase and the lower reporting regarding income in tax returns (2014b), respectively. In this respect, the comparison of net VAT obligation from VAT returns between periods before audits and after audits in our analysis very likely contain the influences of an economic crisis, which could not be captured and quantified via the applied method of analysis. However, all of the studied groups of taxpayers were subject to the effects of crisis: audited taxpayers, as well as the non-audited control group.

As already mentioned in the OECD study (2010) regarding the effective performance of the tax administration's mission, it is obvious that the strategy of modern tax administration in order to influence a taxpayer's behavior cannot be founded solely on enforcement measures. It is important to consider the range of other factors that can have an impact on the individual taxpayer, as well as interrelated factors on a taxpayer's behavior. Still, the fact is that enforcement (deterrent) measures and in this respect particularly audits remain the basic measure of fiscal administration in performing verification activities and preventing tax evasion. The inefficiency of audits as an enforcement measure in 
terms of tax compliance decreases after an audit on some groups of taxpayers, and this obviously has to be considered within the context of the need for prior identification of other factors in tax compliance, such as determining their importance towards taxpayer's behavior and the application of knowledge gained in this manner, together with the traditional (enforcement) measures. It seems that recognizing the importance of other factors is vital in choosing the way and intensity of enforcement measures, as well as for the optimal use of enforcement measures.

\section{References}

Advani, A., Elming, W., Shaw, J. (2015). How long-lasting are the effects of audits? Tax Administration Research Centre, Discussion Paper: 011-15, HM Revenue \& Customs.

Agostini, C. A. \& Martinez, C. (2014). Response of Tax Credit Claims to Tax Enforcement: Evidence from a Quasi-Experiment in Chile. Fiscal Studies 35(1), 41-65. https://doi.org/10.1111/j.1475-5890.2014.12022.x

Aizenman, J. \& Jinjarak, Y. (2008). The collection efficiency of the Value Added Tax: Theory and international evidence. Journal of International Trade and Development 17(3), 391-410. https://doi.org/10.1080/09638190802137059

Ali, M.M., Cecil, W.H., Knoblett, J.A. (2001). The effects of tax rates and enforcement policies on taxpayer compliance: A study of self-employed taxpayers. Atlantic economic journal 29(2), 186-202. https://doi.org/10.1007/BF02299137

Allingham, M.G. \& Sandmo, A. (1972). Income tax evasion: A theoretical analysis. Journal of Public Economics 1, 323-338. https://doi. org/10.1016/0047-2727(72)90010-2

Alm, J., Jackson, B.R., Mckee, M. (1992). Estimating the determinants of Taxpayer compliance with experimental data. National Tax Journal 45(1), 107-114.

Alm, J., Sanchez, I., De Juan, A. (1995). Economic and Noneconomic Factors in Tax Compliance. Kyklos 48(1), 3-18. https://doi. org/10.1111/j.1467-6435.1995.tb02312.x

Bergman, M. \& Nevarez, A. (2006). Do Audits Enhance Compliance? An Empirical Assessment of VAT Enforcement. National Tax Journal 59(4), 817-832. https://doi.org/10.17310/ntj.2006.4.04

Cardillo, G. (2006). Dunn's Test: a procedure for multiple, not parametric, comparisons. Retrieved from http://www.mathworks.com/ matlabcentral/fileexchange/12827

Cardillo, G. (2009). KWTEST, Kruskal-Wallis non parametric test for Analysis Of Variance. Retrieved from http://www.mathworks.com/ matlabcentral/fileexchange/25860

Cardillo, G. (2011). WINSORISING: Winsorising Data. Retrieved from http://www.mathworks.com/matlabcentral/fileexchange/

CASE - Centre for Social and Economic Research - Netherlands Bureau for Economic Policy and Analysis (2013). Study to quantify and analyse the VAT Gap in the EU-27 Member States. Retrieved from http://ec.europa.eu/taxation_customs/resources/documents/ common/publications/studies/vat-gap.pdf

Dubin, A.J. \& Wilde, L. L. (1988). An Empirical Analysis of Federal Income Tax Auditing and Compliance. National Tax Journal 41(1), 61-74.

Gemmell, N. \& Ratto, M. (2012). Behavioral responses to taxpayer audits: Evidence from random taxpayer enquiries. National Tax Journal 65(1), 33-58. https://doi.org/10.17310/ntj.2012.1.02

Hauptman, L., Horvat, M., Korez-Vide, R. (2014). Improving Tax Administration's Services as a Factor of Tax Compliance: The Case of Tax Audit. Lex Localis - Journal of local self-government 12(3), 481-501.

Hoopes, J.L., Mescall, D., Pittman, J.A. (2012). Do IRS audits deter corporate tax avoidance? The accounting review 87(5), $1603-1639$. https://doi.org/10.2308/accr-50187

IMF (2009). Collecting Taxes during an Economic Crisis: Challenges and Policy Options. IMF Staff Position Note. Retrieved from: http:// www.imf.org/external/index.htm

Kamdar, N., (1997). Corporate income tax compliance: A time series analysis. Atlantic economic journal 25(1), 37-49. https://doi. org/10.1007/BF02298475

Kleven, H. J., Knudsen, M. B., Kreiner, C. T., Pedersen, S., Saez, E. (2011). Unwilling or unable to cheat? Evidence from a tax audit experiment in Denmark. Econometrica 79(3), 651-692. https://doi.org/10.3982/ECTA9113

Lešnik, T., Kračun, D., Jagrič, T. (2014a). Recession and Tax Compliance - The Case of Slovenia. Inzinerine Ekonomika - Engineering Economics 25(2),130-140.

Lešnik, T., Kračun, D., Jagrič, T. (2014b). Tax Compliance and Corporate Income Tax - The Case of Slovenia. Lex Localis - Journal of local self-government 12(4), 793-811.

Matthews, K. (2003). VAT Evasion and VAT Avoidance: Is there a European Laffer Curve for VAT? International Review for Applied Economics 17(1), 105-114. https://doi.org/10.1080/713673162

OECD (2008). Monitoring Taxpayer's Compliance: A practical Guide Based on Revenue Body Experience. Forum on Tax Administration: Compliance Sub-group. Retrieved from: http://www.oecd.org/tax/taxadministration/40947920.pdf

OECD (2010). Understanding and Influencing Taxpayers' Compliance Behavior. Forum on Tax Administration: Small / Medium Enterprise (SME) Compliance Subgroup. Retrieved from: http://www.oecd.org/tax/administration/46274793.pdf

Palil, M. R. \& Mustapha, A. F. (2011). Factors affecting tax compliance behavior in self-assessment system. African Journal of Business Management 5(33), 12864-12872. 
Plumley, A. H. (2002). The Impact of the IRS on Voluntary Tax Compliance: Preliminary Empirical Results. National Tax Association, $95^{\text {th }}$ Annual Conference of Taxation. Retrieved from http://www.irs.gov/pub/irs-soi/irsvtc.pdf

Reckon. (2009). Study to quantify and analyze the VAT gap in the EU-25 Member States. Retrieved from http://ec.europa.eu/taxation_ customs/resources/documents/taxation/tax_cooperation/combating_tax_fraud/reckon_report_sep2009.pdf

OECD. (2014). Consumption tax trends 2014. OECD Publishing. Retrieved from http://www.keepeek.com/Digital-Asset-Management/ oecd/taxation/consumption-tax-trends-2014_ctt-2014-en\#page92 https://doi.org/10.1787/ctt-2014-en

\section{Authors}

Ddr. Timotej Jagrič is a full professor for Applied economics and econometrics and full professor for Finance at University of Maribor, Faculty of Economics and Business. He is head of Institute of Finance and Banking and is Certified in Risk Management (CRM). His current focus of research are methods in risk management and artificial intelligence.

Dr. Tomaž Lešnik is employed as an analyst in the Financial Administration of the Republic of Slovenia. He obtained his PhD degree from University of Maribor, Faculty of Economics and Business. His research is focused on the area of public finances, especially on the effectiveness of fiscal measures, taxes, influencing tax compliance and different aspects of fiscal administrations. He has published several scientific and professional papers. The author can be contacted at lesnik.tomaz@amis.net.

\section{Inšpekcijski pregledi kot cepivo ali zgolj Aspirin?}

\section{Izvleček}

Članek se ukvarja z vplivom inšpekcijskih pregledov na prostovoljno izpolnjevanje davčnih obveznosti na področju davka na dodano vrednost v Sloveniji. Analiza pokaže, da davčni zavezanci, pri katerih je bil opravljen inšpekcijski pregled z ugotovljenimi nepravilnostmi, v letu inšpekcijskega pregleda izkazujejo višjo raven izpolnjevanja davčnih obveznosti kot v letu poprej. Medtem pa davčni zavezanci, pri katerih je bil opravljen inšpekcijski pregled v enakem obdobju, vendar brez ugotovljenih nepravilnosti, svojega ravnanja bistveno ne spremenijo. V zvezi z dolgoročnim vplivom inšpekcijskih pregledov pa rezultati analize izkazujejo možnost poslabšanja izpolnjevanja davčnih obveznosti tako v primeru inšpekcijskih pregledov z ugotovljenimi nepravilnostmi kot tudi pri inšpekcijskih pregledih brez ugotovljenih nepravilnosti.

Ključne besede: inšpekcijski pregledi, davek na dodano vrednost, prostovoljno izpolnjevanje davčnih obveznosti 